\title{
WEISS MANFRÉD - EGY MAGYAR VÁLLALKOZÓ EREDMÉNYEI
}

\section{WEISS MANFRÉD. RESULTS OF A HUNGARIAN ENTREPRENEUR}

\author{
Gáti József,, Nagy László, ${ }^{1}$ Kuti János ${ }^{3}$ \\ Óbudai Egyetem, Budapest, Magyarország \\ 1 gati@uni-obuda \\ ${ }^{2}$ nagy.laszlo@hok.uni-obuda.hu \\ ${ }^{3}$ kuti.janos@rh.uni-obuda
}

\begin{abstract}
We are forgetting undeservedly many great technical creators in Hungary, or we don't remember them sufficiently. Manfréd Weiss belongs to these great technical people. In my dissertation I show his life, and work for the technical development. In my „Scientific Student” work beyond the life of this famous inventor engineer, I also discover his technical results and their impact on the posterity. In my dissertation I mention the spirit of that age, in the interest of understanding better the work and the creative environment of the inventor.
\end{abstract}

Keywords: biography, ammunition, Csepel

\section{Összefoglalás}

Több Magyarországon alkotó nagy műszaki alkotót méltatlanul felejtünk el, vagy nem kellőképpen emlékezünk meg róluk. Ezen műszaki nagyjaink közé tartozik Weiss Manfréd is. Kutatásunkban az Ő életét, a technikai fejlődésért tett munkáságát mutatjuk be. Munkánkban a híres feltaláló-mérnök életén túl a műszaki eredményeit és azok az utókorra kiható hatásait is feltárom. Értekezésünkben kitérünk a kor szellemiségére, annak érdekében, hogy jobban meg lehessen érteni a feltaláló munkáságát, alkotói környezetét.

Szeretném kiemelni, hogy az elvégezett feltáró munkánk során felfedeztük, milyen fontos a témaválasztás. Az utókornak kötelessége, hogy feltárja és megismerje elődjei munkáságát, ebből okuljon és minél szélesebb körben terjessze ezt, nyilvánosságra hozza.

Kulcsszavak: technikatörténet, Weiss Manfréd, életrajz, löszer, Csepel.

\section{A Weiss család}

18. század végén Csehországból egy antiszemita hullám miatt rengeteg gazdag zsidó család vándorlót át Magyarországra. Nagyapja Baruch Weiss is ekkor költözött Pestre, ahol Pipa készítő műhelye volt. Édesapja Weiss Adolf termény kereskedő volt. Édesanyja Kanitz Éva előkelő Budai lány volt. Hat gyermekük született, amelyek közül Weiss Manfréd volt a legfiatalabb.

Weiss Manfréd 1857. április 11. született Pesten. A Budapesti Kereskedelmi Akadémián tanult, később Hamburgban gyarmatárú-nagykereskedésben szerzett üzleti tapasztalatot.

\section{A gyár alapításának előzményei}

Magyarországon az ipari fejlődés 1848-at megelőző évtizedekre tehető a manufaktúrák megjelenésével. Ekkoriban a meghatározó iparág a malomipar volt. Az ezt kiszolgáló kereskedelem volt a legmeghatározóbb. A mezőgazdasági és malomipari terményeket elsősorban az osztrák piacra szállították. A szabadságharc leverése után a monarchiában az volt a jellemző, hogy nyugati területekről érkező tőke mozgatta az iparosodást. A századfordulón a gyártulajdonosok, igazgatók $12 \%$, a művezetők $20 \%$, míg a munkások $75 \%$ érkezett a monarchia egyéb országaiból. Ebben az 
időszakban két formája alakult ki gyáralapításnak:

- első: hazai gépinagyiparban a külföldi befektetők támogatásával;

-második: mezőgazdaság exportjellegű kereskedelemből vagyonszerzett kereskedők ipari befektetésével;

1860 és 1880 között a vasút fejlődésének köszönhetően fejlődni kezdett a nehézipar. 1880-as években az ipari forradalom jellemezte a magyar ipart. Ezt követően alakult ki a gyáripar az 1890-es évekre. Az 1860-as évtized végére a Weiss család is ipari tőkéssé vállik.

\section{A vállalkozás kezdete}

1877-ben bátyja Weiss Bertold gabona vállalkozásába betársult. 1878-ban az Osztrák-Magyar Monarchia elfoglalta Bosznia-Hercegovinát a Török Birodalomtól és a Katonai Gabona ellátást többek között a Weiss testvérek vállalata is szállított. A Weiss testvérek 1882. december 28-án engedélyt kaptak, hogy megnyissák a konzervgyárukat, ekkor jegyezte be a bíroság az Első Magyar Konzervgyár társas vállalkozást. Az akkori Magyarországnak ez volt a legelső konzervgyára. A Lövölde térről átköltöztek Máriássy utcába. Később töltényhüvelyeket, katonai palackokat, lőszereket és egyéb hadi felszerelést kezdtek el gyártani. Konzervük Globus néven volt ismert akkoriban. A csomagoláshoz bádogdobozokat kellett használniuk és mivel egyre nagyobb lett a kereslet a konzervükre így azoknak a gyártásába is belekezdtek. Ezzel már a vasipari tevékenységet is végeztek.

Weiss Manfréd üzleti stratégiája az volt, hogy a potenciális kereslethez igazították a termelést és sose az aktuálishoz, habár néha ezek veszteséggel is járhattak, de a jövő, hogy a jövőbe sikeresek legyenek ezt meg kellett tenniük. A testvérpár hamar felismerte, hogy az államnak gyártott hadifelszerelések igen kifizetődő tevékenység. Így kezdték meg a tölténygyártást. 1890-ben azonban a húsárú üzemben tölténygyártás közben hatalmas robbanás történt. Ezután már a hatóságok nem engedélyezték, hogy lőszereket és más robbanás veszélyes termékeket gyártsanak a konzervgyár területén. Ezután egy új gyártelep után kezdtek el kutatni és Csepel szigetre esett a választás. 1892. december 12-én vették bérbe egy homokos területe, aminek a neve János-legelő.

Azért választottak mert közel volt Budapest, olcsó volt a munkaerő, illetve a telek bérleti díja. 1892-ben ide helyezték át az egész gyárat és már a

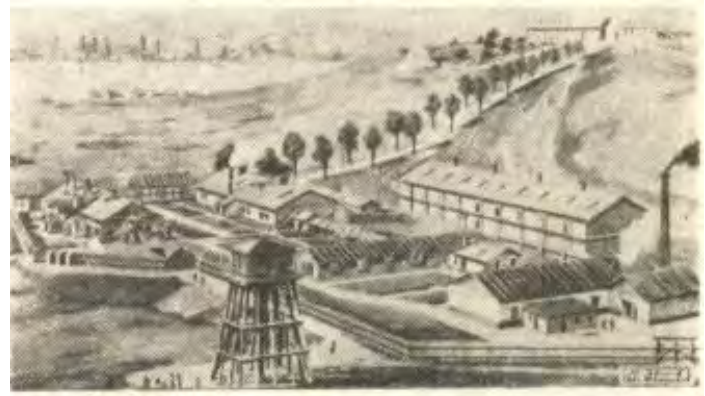

1. ábra. Az első Csepeli gyártelep János-legelőn 1892-ben [3]

hadiipari termékek gyártása összpontosították a termelést. Már jelentős tőkéjük volt, illetve rengeteg jó üzleti kapcsolatai voltak a Weiss testvéreknek ennek köszönhetően a kormány támogatását is élveszték különböző kedvezmények formájában. Körülbelül öt hold területet béreltek. Előszőr 30-40 férfi és 100-110 nő volt foglalkoztatva. A környélbéli falvakból jöttek az emberek dolgozni. 1893. január 12-én kapták meg a vállalkozók ipartelep létesítésére az engedélyt. 1896-ban a bérelt területet felvásárolták. Ekkora a területen 20 épület áll és már 400 munkás folytatta a termelést.

\section{A Önállóság nehézségei}

1896-ban a két testvér szétválik mert Bertoldot parlamenti képviselőnek választják illetve a Textil. Akkoriban az úgy nevezett összeférhetetlenségi törvény miatt kellett a cégből kiszállnia mert nem lehetett egy olyan ember képviselő, akinek a vállalta kapcsolatban állt az akkori magyar kormánnyal.

A következő 20 évben Európa egyik legnagyobb nehézipari központ lett Csepelen. 1893-ban 150 fő volt a dolgozók száma.1917-ben 27.000 ember dolgozott már a gyárban.

1896-1914 között az ország legnagyobb hadiüzemévé fejlődött a gyár. A hatalmas megrendeléseknek köszönhetően és a jó családi kapcsolatoknak is köszönhető, hogy a gyalogsági lőszer termelése illetve az Osztrák-Magyar Monarchia hadseregének a legnagyobb magánszállítója lett. A fejlődésnek köszönhetően 1896-ban ami a gyártáshoz szükséges réz kellett már a saját rézkohászati üzemében állította elő. 1898-99-ben már saját kovácsműhely, víztorony, anyagvizsgáló és még több raktár épület készült el. 1901-ben mozgókonyhákat, főzőládákat, tábori sütőkemencéket, illetve hasonló katonai felszereléseket is gyártot- 


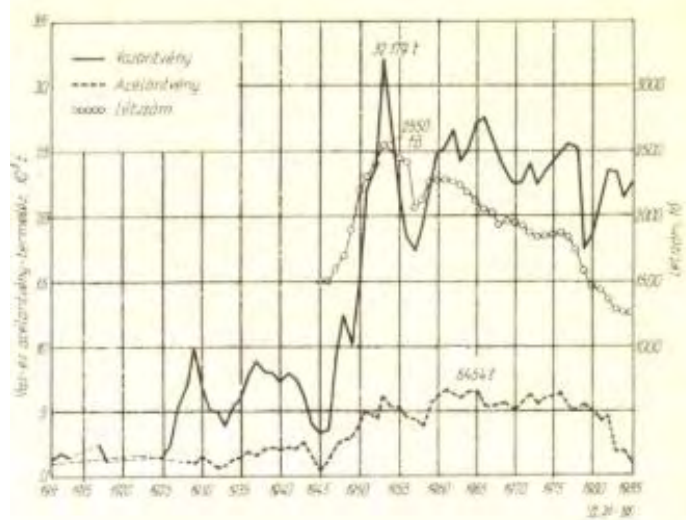

2. ábra. Vas- és acélöntvény gyártás és létszám alakulása a Csepeli öntödében [3]

\begin{tabular}{|l|r|l|l|l|}
\hline Év & Létszám (fố) & $\begin{array}{l}\text { Terület (kat. } \\
\text { Hold) }\end{array}$ & $\begin{array}{l}\text { Épület alapterület } \\
(\mathrm{m} 2)\end{array}$ & $\begin{array}{l}\text { Gépek } \\
\text { teljesítménye (LE) }\end{array}$ \\
\hline $1892-$ & 25 & 5 & 400 & 4 \\
\hline $1892-1896$ & 920 & 5 & 7500 & 160 \\
\hline $1896-1902$ & 3500 & 60 & 13000 & 546 \\
\hline $1902-1910$ & 5000 & 60 & 40000 & 7000 \\
\hline $1910-1914$ & 10000 & 125 & 100000 & 14000 \\
\hline
\end{tabular}

3. ábra. A Csepeli gyár fejlődése számokban az első Világháborúig [5]

tak.1904-ben már a csepeli gyártelep lett az anyavállalat. Csepelre került a kereskedelmi iroda is. 1907 őszére a fémrúd-fémcsőtelep is elkészült. 1911-12-ben saját acélbázis kezdett el kialakítani a cég. Két martinkemencével felépült az acélmű, mely napi szinten biztosította a nyersanyagot.

Az acélmű felépítéséhez 5 millió koronás beruházást tett, de a 10,4 cm felületi tüzérségi lőszerek 42\% kvótáját kérte az államtól. 1911-ben titkos szerződést kötött a Witkowitzi vasművel. A szerződés főbb pontjai:

- a Witkowitzi vasművek kötelezi magát a lövedékgyártásban szerzett tapasztalatainak átadására Weiss Manfréd számára. Mérnököket és munkásokat is küld Csepelre;

- Weiss Manfréd kötelezi magát, hogy minden

a haditengerésztnek szállított lövedék után 3,5\%-ot fizet Witkowitznak. Witkowitz támogatja Weiss Manfrédot, hogy a haditengerészetől elnyerje a 30,5 ágyúlövedékek beszállítását;

- Weiss Manfréd minden olyan berendezést, amit külföldön lehet megvenni az csak Witkowitztől veheti meg;

- Weiss Manfréd a Witkowitztől átvett tapasztalatokat nem adhatja tovább, azoknak a gyáraknak sem, ahol Weiss Manfréd résztulajdonos;

Amikor a gyárnak a kezdeti időszakban nem ment annyira a termelés a cég vagyonát Weiss
Manfréd ingatlan vásárlásba fektette. Megvásárolta a mai Jókai út, Nagymező utca, Új-Lipót város déli része mely: a Margit hídtól a Vígszínházig terjedt és az Andrássy utat is. 1915-ban a Károlyi-kastélyt Derekegyházán megvásárolta.

A korszak legkeményebb gyára volt. Manfréd is munka mániás volt mindenből a legjobbat akarta kihozni szigorúan a profitot előtérbe helyezve. A világháború kitörésével Weiss Manfréd már tudta, hogy vállalkozásának fejlődésének egy hatalmas löketet adhat. Az egyéni vállalkozását családi részvénytársaságra alakította át. Ebben az időszakban vezette a három műszakos munkarendet, hogy a termelést növelni tudja. Egy újabb martinkemencével bővítették a gyártást, illetve beszerezték az első elektrokemencét is. 1917-ben volt a gyár legnagyobb forgalma - a Generál Biztosító kö - rülbelül 100 millió koronára becsülte meg az egész csepeli gyár értékét.

\section{A Csepeli fejlesztések}

Weiss Manfréd nem csak a saját gyárát fejlesztette hanem Csepel és környékét, illetve jótékonykodott is. A gyár alapításakor Csepel egy jelentéktelen kisközség volt alig több mint 2200 lakossal. 1896-ban a legmodernebb minta szerint felépített egy munkásszállót. Gyári jótékonykodást is létesített: gyári csecsemőotthon. Egy napos kortól egészen hatéves korig felügyeltek a gyermekekre ezzel segítve a gyárban dolgozó nők minden napjain. Csepelen a Ferenc utcába volt a Nép konyha, ahol naponta 1000 adag ételt osztottak ki. 1914-ben a Váci utcába is nyitottak egy Nép konyhát, ahol ugyan úgy körülbelül 1000 adag ételt osztottak ki. Ekkoriban a második legnagyobb étel osztó konyha volt. Körülbelül 1.600 .000 embert láttak el a világháború alatt. 1916-ban létrehoztak egy gyári korházat, hogy a termelésben történő baleseteket hamar eltudják látni. De nem csak a gyárban dolgozók vehették igénybe, hanem a Csepel lakossága is igénybe vehették. Sürgősségi ellátás is volt a korházban. 1910-ben felesége emlékére a kor legmodernebb budapesti szülő otthonát hozta létre. Itt volt előszőr szervezett terhes tanácsadás. Saját nővér képzővel is rendelkezett ez a szülőotthon. Ingyenes volt és 1910-18 között több mint 5000 gyerek látott napvilágot. Ezen kívül Manfréd iskolát és óvodát is építtetett Csepelnek. Ezeknek a fejlődéseknek hála már 1910-ben már közel tízezren laktak Csepelen.

Weiss Manfréd gyára mivel ilyen nagy ütemben elkezdett nőni így 1905-től a Pesti Magyar Kereskedelmi Banknak igazgatósági tagja lett és 
a Gyáriparosok Országos Szövetségnek. Ezután a kecskeméti konzervgyárat is felvásárolta majd később néhány textilüzemet is.

\section{Kitüntetések}

Weiss Manfréd 1896. augusztus 16-án, I. Ferenc József osztrák császár és magyar király nemességet, illetve csepeli nemesi előnevet adományozott.

A párizsi világkiállításon, ami 1901-ben volt megkapta a „Vaskoronarend” és „Ferenc József-rend” középkeresztjét is megkapta a nagymérvü hadfelszerelés érdekében kifejtett tevékenységének elismeréseként. 1915-ben felsőházi tag lett.

1918. november 16-án pedig bárói címet adományozott neki IV. Károly osztrák császár és magyar király az Osztrák-Magyar Monarchia egyik legnagyobb hadianyag szállítójaként.

\section{Weiss Manfréd Családja}

Weiss Manfréd felesége Bécsből származott. Egy osztrák vasúti vállalkozó lányát vette el feleségül amelynek neve Wahl Alice egy lovagi család sarja. Rövid időn belül hat gyermekük született. Négy lányuk és két fiúk: Weiss Elza, Weiss Edith, Weiss Marianne, Weiss Daisy, Weiss Alfons és Weiss Jenő.

Szigorú szülök voltak, megvolt határozva mikor volt a tanulás, illetve mikor volt a pihenés. Hetente egyszer Weiss Manfréd a családdal zeneesetet tartott, ahol ő maga hegedült felesége pedig zongorázott. Unokái elmondásai alapján nagyapjuk fejfájós és rossz alvó volt. Az Andrássy úti házukban élték minden napjaikat. Weiss Manfréd felesége 1904. januárjába 39 évesen hunyt el vérszegénységben. Fiai Weiss Jenő és Weiss Alfons mérnöknek tanultak, hogy később segíteni tudják apjuk vállalkozását.

\section{Az államosítás és következményei}

1919-ben a Tanácsköztársaság idején államosították a gyárat. Manfrédnak a gyár annyira az élete volt, hogy öngyilkosságot kísérelt meg de munkásai megmentették. Budapestre mikor bevonultak a románok leszerelték a gyárat. 28.000 munkásból csak 6.000 fő maradt meg. Trianon után a hadiiparról béke cikkek gyártásba kezdtek.

Öngyilkosság megpróbálása után már nem volt az igazi Manfréd. 1922. december 25-én agyvér-

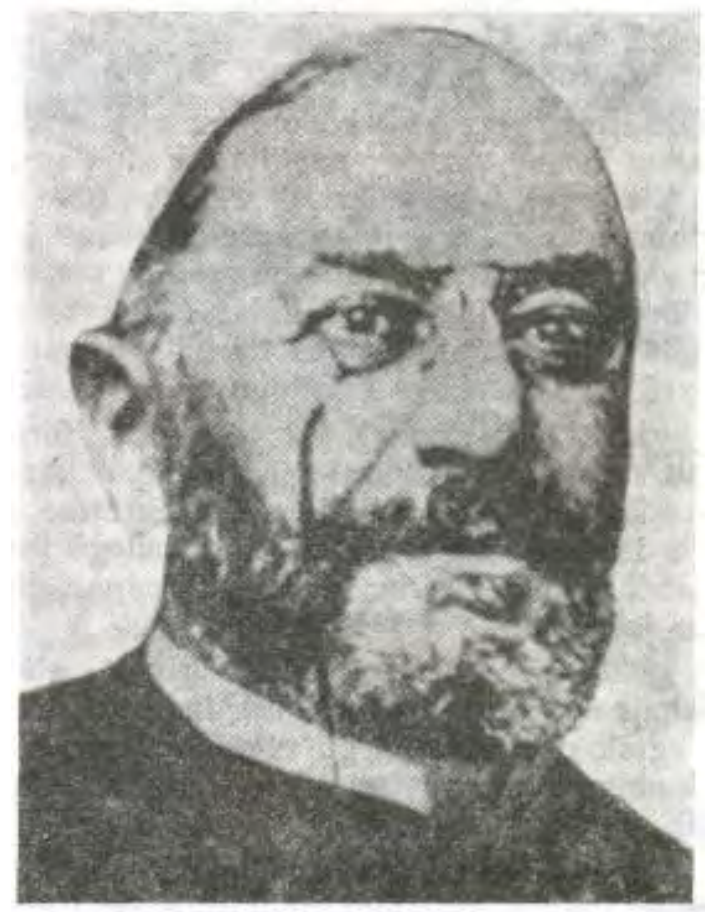

4. ábra. Weiss Manfréd

zésben elhunyt. A Csepeli Gyártelep első korszaka Weiss Manfréd halálával lezárult.

\section{8. Összefoglalás}

Weiss Manfréd a magyar gyáriparosok egyik legkiválóbb képviselője volt, műszaki és gazdasági szemlélete kiemelte a korszakból és az egyik legnagyobb gyártulajdonossá tette. Életét és munkásságát sokan ismerik, ugyanakkor kiemelendő, hogy szociális munkásága, munkásaival való bánásmódja. Személyisége miatt ma is egy kiemelkedő példaképe a magyar műszaki ifjúságnak, kitartása és gondolkodása követendő példa.

\section{Szakirodalmi hivatkozások}

[1]Lengyel József: 75 éves a Csepeli acélgyártás. Csepeli Müszaki-Közgazdasági szemle 1987/1.

[2] Csepeli müvek II. Ad_275-278-2009, Ad_280-2009.

[3] Rácz József: 75 éves a vas és acélöntvény-gyártás Csepelen, Bányászati és kohászati lapok 38/6.

[4] Kálmán Lajos: 50 éve gyártják vas- és acélöntvényeket Csepelen, Öntöde 14/2.

[5] A Csepel vas- és fémművek rövid áttekintése 